Nama : Arvin Winatha

Email : s130119032@student.ubaya.ac.id

\title{
The Phenomenon of Competitive Human Resources and How It Impacts
}

\section{Business Growth}

Increasingly tight business competition map of industry has been the main focus for everyone in the world, especially in the industry we call it as the Industry era 4.0 . The awareness of this competiton has made many business organizations in the world, including Indonesia busy preparing themselves, particularly those related to the development of human resources, to be ready to compete in this global era. The Fourth wave of industrial revolution is marked by the use of information technology, artificial intelligence, and automatic engines or vehicles that have been going on since years before.

In the last 3 years, Indonesia's economy has grown above 5\%. The Government also seems to have full support and commited to building a globally competitive manufacturing industry through the acceleration of implementation of industry 4.0, given that the national industry desperately needs connectivity and interaction through integrated technologies, information and communications.

Today and in the future, competitive advantage has become a necessity for every business actor when he wants to compete in the global market. This condition will encourage the occurrence of massive transformation at all business levels and units. One determinant to be able to innovate ceaselessly is the readiness of the business world in building and preparing excellent and global quality human resources, in the sense of having talent with high competency standards in their respective field and having strong character that can compete for any firm at global level. Human Resource Development has been a key strategy to many global companies in the world for dealing with global era competition so as not to be drowned by the changing of times. Every business is required to have a high commitment in preparing and building competitive human resources, concerns about the readiness of business organizations to compete in global era are quite reasonable due to rapid movement on this globalization, technological advances, and the demographic pattern shift.

Indonesia's Human Development Index (HDI) score in 2017 was 70,81 and on 2019 Indonesia's HDI value is 0,718 , which put the country in the high human development category. HDI is a summary measure for assessing long-term progress in three basic dimensions of human development including a long and healthy life, access to knowledge and a decent standard of living. However, the quality of the Human resources are still questionable, mainly cause by difficult access to schools, poverty and the government policies that haven't prioritized on the development of human resource quality. Low quality of human resources in Indonesia or any developing countries are the low achievement of formal education and the low basic competencies of the students. 
Indonesia desperately needs superior human resources as a basic capital, given the disruption of technology that marks the industrial revolution 4.0 has changed the political dan economic landscape that resulted in the loss of a lot of jobs replaced by technological process. Automation will indeed eliminate old jobs, but it can bring new jobs. As we could see ,for example on Financial Businesses, Nowadays Banks in the world are slowly start to move their focus step by step on developing the digital apps so in the future perhaps we could see the digital banks start to be able to access everywhere, that in this case could reduce the number of real office and also the number of employees the company needs. This movement might be a threat for human resources if they not transforming to be a better quality in the future, because human resources have to fight against the rapid change of technology.

In General, employee work productivity is directly proportional to the high competitiveness of the organization as a whole in the face of business competition. Excellent business or company is a company that always adaptive to change, only companies that are adaptive to change that can survive in a global era. To make a change, the new ways and method that companies are able to apply usually require business and human resource transformation through some development things. Development is usually done through training activities and corporate culture understanding to improve the knowledge and skills of employees. Company leaders do have a big challenge to drive different individuals within the organization to realize their vision and mission despite the dynamics of change. Leaders of large and medium companies in Indonesia are aware of the increasingly tight fee competition map and trying to encourage human resources to be ready to compete at global level, such as PT. Bank BRI was succeeded in making changes by developing 5 basic cultures, namely integrity, professionalism, satisfication, exemplary and reward/respect for Human Resources. These cultures provide Bank BRI to be able to compete at global level.

Company environment, motivation and innovation strongly encourage employees to provide the best performance and expected to get a balanced compensation. Company leaders will be more benefited when they have talented employees and a condusive working environment. The combination of commitment and satisfication has proven to be able to increase the company performance, including human resources productivity.

It comes to a conclusion, in the future the war for talent issues will be the main agenda of corporate leaders in order to face the digital era economy. The Human Resources talent must be able to show up and obtain optimal and sustainable results, as well as the company is expected to build the organization capability as reflected in the management strategy and performance. (Zafrullah Tayibnapis et al., 2018) 


\section{DAFTAR PUSTAKA}

Zafrullah Tayibnapis, A., Wuryaningsih Endang, L., \& Azizi, G. N. (2018). Indonesia's Efforts to Achieve Globally Competitive Human Resources. International Journal of Humanities and Social Science Invention (IJHSSI), 7(08), 1-6. https://doi.org/10.31227/osf.io/q7pdv 